\title{
Pathological Scanning of Ochratoxigenic Moulds Impaired Feed In Vivo, Towards Conceptualizing their Reverberations on Different Organs
}

\author{
Benjamin T. Thomas*, Omolara D. Popoola, Moses O. Efuntoye, Mercy O. Coker and \\ Ahmed O. Tajudeen \\ Department of Microbiology, Olabisi Onabanjo University, Ago Iwoye, Ogun State, Nigeria \\ *Corresponding author, email address: benthoa2013@gmail.com \\ Co-authors'emails: dorcasatmoment@gmail.com (Popoola); mosolatoye@yahoo.com (Efuntoye); \\ Olawunmimercy707@gmail.com (Coker); tajudeen.ahmed5236@gmail.com (Tajudeen) \\ Received 25 Jan 2021, Revised 25 Apr 2021, Accepted 3 May 2021, Published May 2021 \\ DOI: https://dx.doi.org/10.4314/tjs.v47i2.18
}

\begin{abstract}
The role of ochratoxigenic moulds in causing several invasive diseases has been documented but little is known about the effects of these ochratoxigenic moulds contaminated feeds in a laboratory control experiment. This study therefore, examined the pathological effects of ochratoxigenic moulds contaminated feed in order to understand their reverberations on different organs. Thirty two albino rats were randomly assigned to four experimental treatments (T) with eight rats per treatment (T1, T2, T3 and T4). T1 and T2 were female and male control rats, respectively that were fed normal feed, while T3 and T4 were male and female experimental rats that were fed with ochratoxigenic moulds contaminated feed for a period of two weeks. Serum alanine aminotransferase (ALT), aspartate aminotransferase (AST), alkaline phosphate (ALP), acid phosphate (ACP), total protein, albumin and histopathological analysis of different organs, namely liver, heart, kidney, stomach, small intestine, lungs, brains and spleens were carried out following standard protocols. Results obtained depicted varying levels of serum concentrations of total protein, albumins, AST, ACP, ALT and ALP between treatments and control groups $(\mathrm{p}<0.05)$. Photomicrograph examinations of the different organs examined reveal degenerative changes in the ultra-structural integrity of all the organs as compared to the control groups except for the spleen where there was no difference between the control and the treatment group.
\end{abstract}

Keywords: Pathology, scanning, ochratoxigenic moulds, reverberations.

\section{Introduction}

The elevated trends (approximately between $8-18 \%$ ) of cereal commodities, seeds, fruits and vegetables lost during post-harvest handling, processing and storage especially in the developing continents of the world including Asia and Africa have been documented (FAO 2011). These losses are due to the unusual growth of fungi and production of their secondary metabolites (mycotoxins) in those commodities (Atef et al. 2018). These secondary metabolites (mycotoxins) are often found as natural contaminants in raw ingredients of poultry feeds (Khan et al. 2011) among other food products including cassava flakes (Thomas et al. 2012) and their production in these food products is contingent upon the availability of some favourable physicochemical parameters including water activity, $\mathrm{pH}$ and temperature (Thomas et al. 2014).

The ochratoxins producing fungal contaminants belong predominantly to two main genera, namely Penicillium and 
Thomas at al. - Pathological scanning of ochratoxigenic moulds impaired feed in vivo ...

Aspergillus spp (Akande et al. 2006), hence they are referred to as ochratoxigenic moulds because of their ability to produce ochratoxins including ochratoxin-A, ochratoxin-B and ochratoxin-C. Of these ochratoxins, ochratoxin-A (OTA) has become the most crucial due to their recognized toxicity and cosmopolitan presence in different feeds (Pozzo et al. 2013). This toxin also represents the greatest health risks in tropical Africa and the rest of the world due to the high toxicity (Manjula et al. 2009, Alborch et al. 2012).

In Nigeria, contaminations of animal basedfoods with mycotoxins occur mainly through direct means or indirectly via contaminated feeds with the latter being the main problem. These mycotoxins when ingested put the consumers at risk of developing mycotoxicosis with potential toxicity on different organs of the body (Jayeola and Oluwadun 2010), while vulnerability of the consumers to these toxins may also be dependent on physiological, genetic and environmental factors. The ability of ochratoxin A to deteriorate different membranes by interfering with the synthesis of various macromolecules and functions has been documented (Iheshiulor et al. 2011). They further emphasize that some of these toxins are neurotoxic and cause different diseases to body organs thereby activating endocrine mechanisms including stress-induced release of corticosteroids that inhibit immune functions. This study was therefore, aimed at providing histopathological scanning of ochratoxigenic moulds impaired feeds in an animal model in order to understand their reverberations on different organs since little is known about the effects of this toxin and the food they contaminate in controlled laboratory experiments.

\section{Materials and Methods \\ Ethical approval}

This study was performed in strict accordance with recommendations in the guide for the care and use of laboratory animals of the National Institute of Health. The protocol was approved by the Ethics in Research Committee of the
Olabisi Onabanjo University, Ago Iwoye, Ogun State, Nigeria.

\section{Sources of Aspergillus ochraceus}

The ochratoxigenic Aspergillus ochraceus used in this study was isolated from processed Manihot esculenta (garri) in our previous study (Thomas et al. 2017) and was screened for ochratoxin-A production using molecular and ELISA techniques as explained below.

DNA isolation, amplification and sequencing Prior to extracting the genomic DNA of the ochratoxin producing Aspergillus ochraceus, the organism was inoculated into $200 \mathrm{~mL}$ sterile saline, pre-incubated at $99{ }^{\circ} \mathrm{C}$ for $20 \mathrm{~min}$ and extracted using a QIAamp DNA mini kit (Qiagen) (Hilden, Germany) as described by the manufacturer. The amplification of the extracted DNA was done by using degenerate primer pairs KAF1/KAR2 (KAF1: 5'GARKSICAYGGIACIGGIAC-3',KAR25' CCAYTGIGCICCYTGICCIGTRAA-3')

(Amnuaykanjanasin et al. 2005). PCR was performed in $0.2 \mathrm{~mL}$ reaction tubes in a final volume of $50 \mu \mathrm{L}$ containing $10 \mathrm{ng}$ of DNA, 1.5 $\mu \mathrm{L}$ Platinum Taq DNA polymerase (Invitrogen) (Waltman, USA), $200 \mathrm{mM}$ each of dATP, dGTP and dCTP, $400 \mathrm{mM}$ dUTP (instead of dTTP), $20 \mathrm{mM}$ Tris $\mathrm{HCl}(\mathrm{pH} \mathrm{8.4)}$, $50 \mathrm{mM} \mathrm{MgCl} 2,0.4 \mathrm{mM}$ each primer and $1 \mu \mathrm{L}$ uracil-N-glycosylase. The amplification conditions were as follows: first and second hold at $50{ }^{\circ} \mathrm{C}$ and $95^{\circ} \mathrm{C}$ for 5 min each to allow uracil-N-glycosylase activity and Taq activation, respectively. These were followed by 35 cycles at $95{ }^{\circ} \mathrm{C}, 62{ }^{\circ} \mathrm{C}$ and $72{ }^{\circ} \mathrm{C}$ for 30 $\mathrm{s}, 1 \mathrm{~min}$ and $2 \mathrm{~min}$, respectively with a final extension step at $72{ }^{\circ} \mathrm{C}$ for $5 \mathrm{~min}$. The visualization of amplified product was carried out on agarose gels prior to purification and sequencing on a 310 auto Genetic Analyzer (PerkinElmer, Applied Biosystems Div., Waltham, USA) with the same primers. The human $\beta$-globin gene primer was used as an extraction/amplification internal control. The sequenced data was subsequently analyzed by using the BLAST database. 


\section{Sample preparation, extraction and quantitation}

The studied ochratoxigenic mould was sub cultured in sabouraud dextrose broth. Then 25 $\mathrm{mL}$ of $50 \%$ methanol was added. The content was shaken vigorously for $3 \mathrm{~min}$ on the horizontal shaker. A $5 \mathrm{~mL}$ aliquot of the resulting solution was filtered using the Neogen filter $(45 \mu \mathrm{m})$ syringe, into the Neogen collecting tube. The amounts of OTA in the organism were determined using a competitive direct enzyme-linked immunosorbent assay (CD-ELISA). Screening method for the analysis was done using Neogen Veratox ${ }^{\circledR}$ (Thermo Lab system, Thermo, Finland) testing kits with limits of detection of $1 \mu \mathrm{g} / \mathrm{kg}$ (ppb) for OTA. Free OTA in the samples and controls were allowed to compete with enzyme-labelled OTA (conjugates) for the antibody binding sites. After a wash step, substrate was added, which reacts with the bound conjugate to produce blue colour. Bluer colour means less OTA, while more pink means more OTA. The test was read in a microtitre reader (Thermo Lab system, Thermo, Finland) to yield optical density. The exact concentration of OTA in the organism was extrapolated after plotting the organism optical density against the standard curve which was derived from the optical density of the control form.

\section{Experimental animals}

Thirty-two (32) apparently healthy albino Wistar rats (16 each of male and female) were procured from the Faculty of Pharmacy, Olabisi Onabanjo University (OOU), Sagamu campus, Ogun State, Nigeria. These Wistar rats were 6 months old at the time of procurement and weighed between 180 and $200 \mathrm{~g}$. Prior to the commencement of the experiment, the rats were acclimatized under laboratory conditions of $27 \pm 2{ }^{\circ} \mathrm{C}$ and $65 \pm 2 \%$ relative humidity in the experimental animal house for one week. The rats were randomized into four experimental treatments $(\mathrm{T})$ with eight rats per treatment. These rats were kept in a wellventilated animal house in wooden cages (65 $\mathrm{cm} \times 35 \mathrm{~cm} \times 50 \mathrm{~cm}$ ) and given free access to clean drinking water and food.

\section{Preparation of ochratoxigenic moulds} contaminated food

Already confirmed ochratoxigenic mould isolated from processed cassava flakes and appropriately screened for OTA production using both ELISA and molecular techniques by Dr. B.T. Thomas of the Department of Microbiology, Olabisi Onabanjo University, Ago Iwoye, Ogun State, Nigeria was used. This isolate, specifically Aspergillus ochraceus, was inoculated on sabouraud dextrose broth and incubated in Erlenmayer flask for 21 days at 27 ${ }^{\circ} \mathrm{C}$. The superficial mycelium from the flask was suspended in culture broth and homogenized with a laboratory mixer. Then, the cell suspension was extracted in saline $(0.85 \% \mathrm{NaCl})$ in the proportion $1: 2$ for $48 \mathrm{hrs}$ at $4{ }^{\circ} \mathrm{C}$, with intermittent disruption of cells by 10 -fold freezing and thawing. The supernatant was separated by centrifugation, dialyzed against tap water for $48 \mathrm{hrs}$ and then against distilled water for $24 \mathrm{hrs}$ and finally lyophilized. The lyophilized organism was mixed with grower's mash at precise concentration of $10 \mathrm{~g}$ of the moulds to $100 \mathrm{~g}$ of the mash and was subsequently stirred for even distribution of the organism in the feed.

\section{Feeding of the experimental animals}

The experimental animals were grouped into four treatment groups as follows: the first and second groups contained eight male and female Wistar rats, respectively that served as control and were fed with the standard diet that is free of any contaminants. The third group contained eight male rats that were exposed to the ochratoxigenic mould contaminated feed for a period of two weeks. The last treatment group (group four) had eight female Wistar rats that were exposed to the same feed as group three. All the experimental protocol was conducted in accordance with the regulations of the local ethics committee in animal care unit of Olabisi Onabanjo University, Ago Iwoye, Ogun State, Nigeria. The ethical guidelines of animal 
Thomas at al. - Pathological scanning of ochratoxigenic moulds impaired feed in vivo ...

experimentation (Regulation CEE 86/ 609) were followed in all experiments. The care of the animals was done in accordance with the U.S. public health service guidelines (NRC 2011).

Sacrificing of animals and harvesting of organs

At the end of the treatment period of two weeks, all thirty-two rats were subjected to overnight fast and sacrificed by dissecting them. Prior to dissection, each rat was introduced into a desiccator and was anaesthetized using chloroform soaked cotton wool for an upward of sixty (60) seconds. As the animal attained unconscious state, it was quickly brought unto the dissection table where it was carefully opened up and the blood collected by heart puncture using syringe and needles, was transferred into a sterile anticoagulated sample bottles to prevent clotting of the blood and for effective biochemical analysis, while eight organs were harvested in all which included the liver, spleen, kidney, small intestine, lungs, heart, stomach and the brain with the aid of forceps and surgical scissors. The organs were kept to fixative containing the prepared $10 \%$ normal formaldehyde for histopathological analysis.

\section{Biochemical parameters}

Serum samples were analyzed for serum alanine aminotransferases (ALT) and aspartate aminotransferases (AST) using the standard colorimetric method of Reitman and Frankel (1957). Alkaline phosphate (ALP) activity was estimated using Randox commercial enzyme kit as described by German Society for Clinical Chemistry (1972), while both the serum total protein and albumin were measured as described by Gradwohl et al. (1980) and Webster (1977), respectively.

\section{Histopathological analysis of the harvested organs}

The processing and sectioning of the harvested organs which include kidney, liver, spleen, lungs, brain, heart, spleen and small intestine were done at 4-5 $\mu \mathrm{m}$ thick and stained using Haematoxylin-Eosin (H\&E) dye before mounting in neutral DPX medium for examination under the light microscope at 100X and 400X magnifications. Photomicrographs were obtained using a scope exe camera attached to a computer.

\section{Results}

Table 1 shows the levels of total proteins, albumin, AST, ACP, ALT and ALP in the blood of the experimental rats exposed to ochratoxigenic mould contaminated food for two weeks. Serum concentrations of total proteins, albumin, AST, ACP, ALT and ALP in the experimental rats were significantly different $(\mathrm{p}<0.05)$. T2 recorded the lowest concentration of total protein compared to T1, T3 and T4. The T4 rats had significant higher $(p<0.05)$ level of total protein than the other treatments. Albumin concentration was lowest in T1 and highest in T4. AST level was significantly higher in T3 when compared with $\mathrm{T} 1, \mathrm{~T} 2$ and $\mathrm{T} 4$ but was lowest in T1. The levels of ALT and ACP were also significantly higher $(\mathrm{p}<0.05)$ in $\mathrm{T} 4$ and $\mathrm{T} 3$, respectively compared to other treatments. The ALP concentration was highest in $\mathrm{T} 3$ and lowest in $\mathrm{T} 2$. 
Tanz. J. Sci. Vol. 47(2), 2021

Table 1: Biochemical parameters of rats exposed to ochratoxigenic moulds impaired feed

\begin{tabular}{|c|c|c|c|c|c|c|c|}
\hline \multirow{2}{*}{$\begin{array}{l}\text { Biochemical } \\
\text { parameters }\end{array}$} & \multicolumn{7}{|c|}{ Treatment groups } \\
\hline & $\mathrm{n}$ & $\mathrm{T} 1$ & $\mathrm{~T} 2$ & $\mathrm{~T} 3$ & T4 & F-value & P-value \\
\hline Total protein $(\mathrm{g} / \mathrm{L})$ & 8 & $19.23 \pm 1.13$ & $19.11 \pm 1.38$ & $21.68 \pm 0.84$ & $21.76 \pm 1.62$ & 10.61 & $<0.05$ \\
\hline Albumin $(\mathrm{g} / \mathrm{L})$ & 8 & $2.01 \pm 0.08$ & $2.04 \pm 0.06$ & $2.84 \pm 0.32$ & $3.06 \pm 0.20$ & 59.32 & $<0.05$ \\
\hline $\begin{array}{l}\text { Aspartate } \\
\text { Aminotransferase } \\
(\text { AST })(\mu g / L) \\
\text { Alanine }\end{array}$ & 8 & $20.94 \pm 1.28$ & $21.86 \pm 1.54$ & $24.24 \pm 2.49$ & $23.85 \pm 2.52$ & 4.82 & $<0.05$ \\
\hline $\begin{array}{l}\text { Aminotransferase } \\
(\text { ALT })(\mu \mathrm{g} / \mathrm{L})\end{array}$ & 8 & $17.20 \pm 1.73$ & $17.09 \pm 1.91$ & $19.63 \pm 0.92$ & $20.23 \pm 1.96$ & 7.43 & $<0.05$ \\
\hline $\begin{array}{l}\text { Acid phosphatase } \\
\text { ACP }(\mu \mathrm{g} / \mathrm{L}) \\
\text { Alkaline }\end{array}$ & 8 & $16.78 \pm 1.01$ & $17.34 \pm 1.34$ & $21.26 \pm 1.53$ & $21.08 \pm 1.34$ & 26.16 & $<0.05$ \\
\hline $\begin{array}{l}\text { Phosphatase (ALP) } \\
(\mu \mathrm{g} / \mathrm{L})\end{array}$ & 8 & $16.51 \pm 0.70$ & $16.12 \pm 0.69$ & $20.24 \pm 1.11$ & $20.19 \pm 1.21$ & 44.26 & $<0.05$ \\
\hline
\end{tabular}

The histopathological examination of the harvested organs of both the control and experimental rats are shown in Plates 1-8. The liver sections of $\mathrm{T} 1$ and $\mathrm{T} 2$ shows hepatic tissue with normal liver cell architecture while that of $\mathrm{T} 3$ and $\mathrm{T} 4$ reveals increasing levels of distorted histoarchitecture, necrosis, blood retention and large central veins. The heart of the $\mathrm{T} 3$ and $\mathrm{T} 4$ rats present with abnormalities of tender and dead tissues when compared with those in $\mathrm{T} 1$ and $\mathrm{T} 2$ rats. As for the kidney, T3 and $\mathrm{T} 4$ rats revealed poor kidney architecture

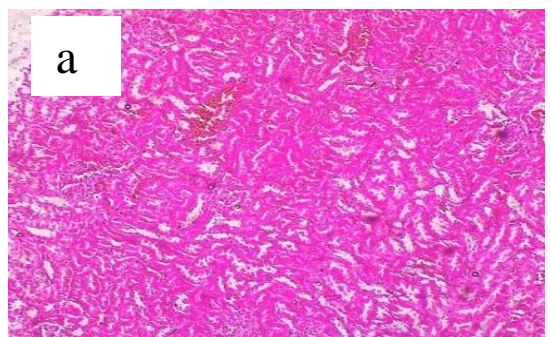

Plate 1 (a \& b): Photomicrograph of liver (T1 and T2). H \& E X100: showing normal histoarchitecture of the liver. and fluid retention when compared with $\mathrm{T} 1$ and $\mathrm{T} 2$. The stomach of $\mathrm{T} 3$ and $\mathrm{T} 4$ rats also connoted significant ulceration. The small intestine, the lungs and the brains showed alterations of mucosal linings, tender necrotic lungs, multiple apoptotic cells in situ at the hypocampus and in the cortex region of the brain, respectively. The spleens however, were not damaged by the action of the ingested ochratoxigenic moulds.

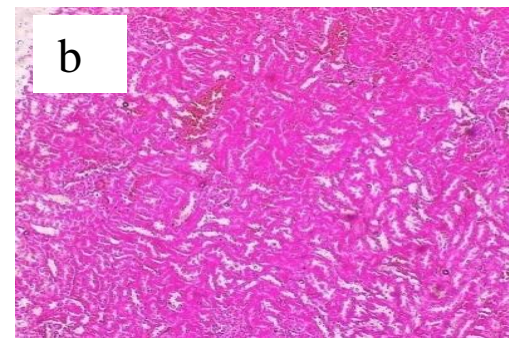


Thomas at al. - Pathological scanning of ochratoxigenic moulds impaired feed in vivo ...
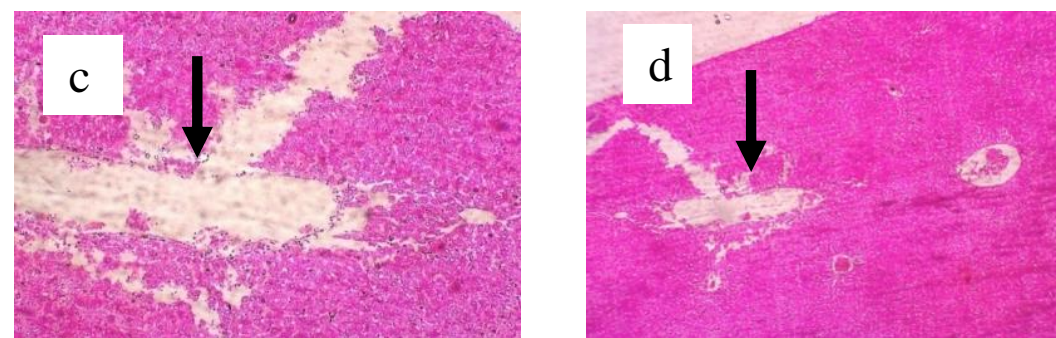

Plate 1 (c \& d): Photomicrograph of liver (T3 and T4) exposed to ochratoxigenic mould contaminated feed. H \& E X100: Showing slightly distorted histoarchitecture, necrosis and blood retention when compared with the $\mathrm{T} 1$ and $\mathrm{T} 2$ rats.
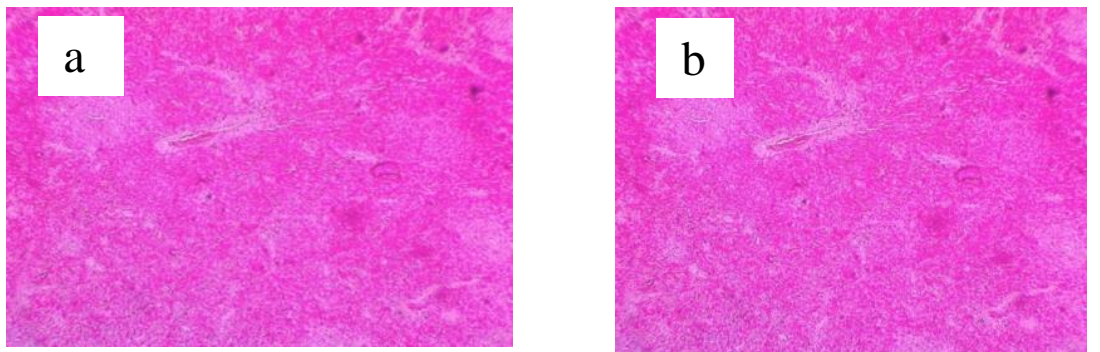

Plate 2 (a \& b): Photomicrograph of $\mathrm{T} 1$ and $\mathrm{T} 2$ heart, $\mathrm{H}$ \& $\mathrm{E}$ X100: showing normal histoarchitecture of the heart.
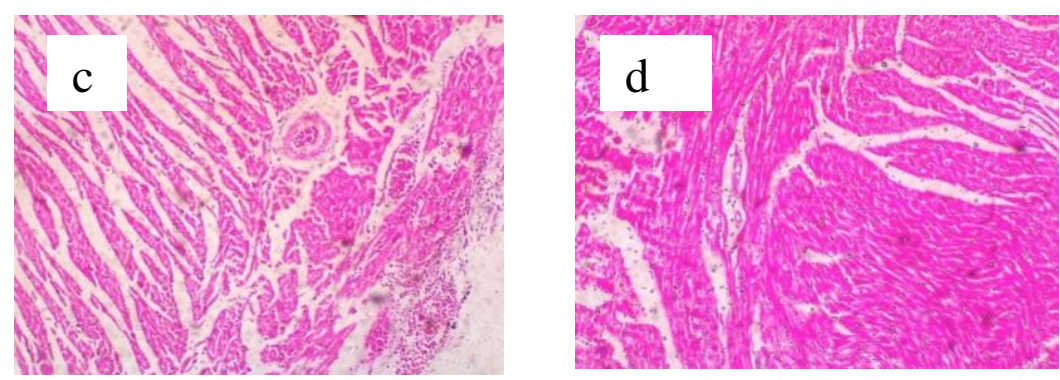

Plate 2 (c \& d): Photomicrograph of heart (T3 \& T4) exposed to ochratoxigenic mould contaminated feed. H \& E X100: showing tender and dead tissues when compared with $\mathrm{T} 1$ and $\mathrm{T} 2$.
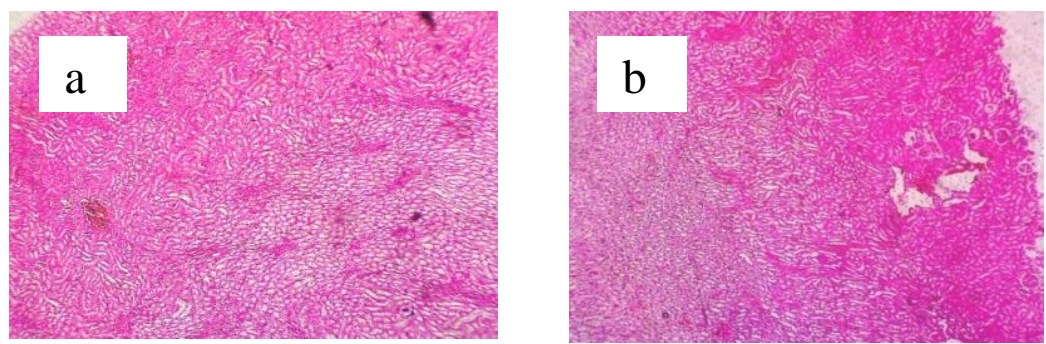

Plate 3 (a \& b): Photomicrograph of T1 and T2 kidney, H \& E X100: showing normal histoarchitecture of the kidney. 

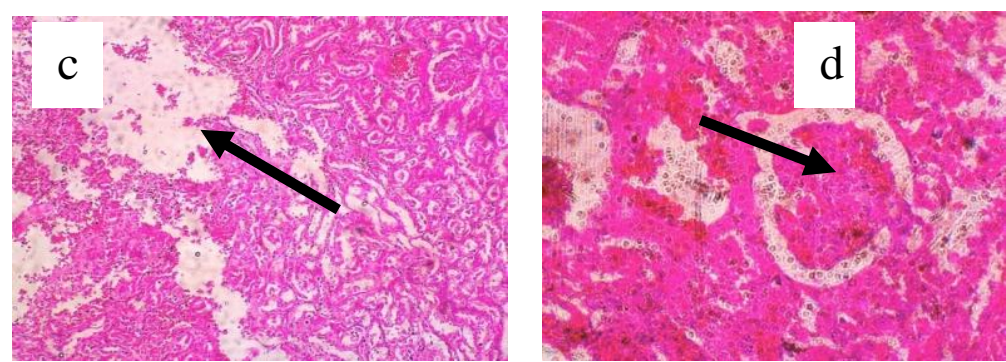

Plate 3 (c \& d): Photomicrograph of kidney (T3 \& T4) exposed to ochratoxigenic mould contaminated feed. H \& E X100: showing poor kidney architecture and fluid retention when compared with $\mathrm{T} 1$ and $\mathrm{T} 2$.
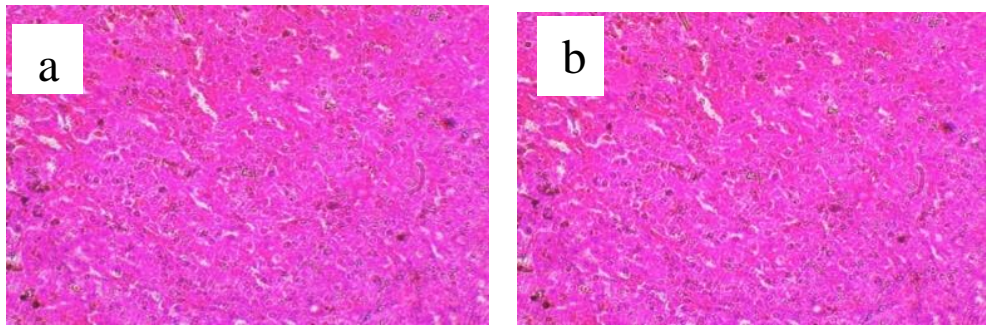

Plate 4 (a \& b): Photomicrograph of T1 and T2 stomach, H \& E X100: showing normal histoarchitecture of the stomach.
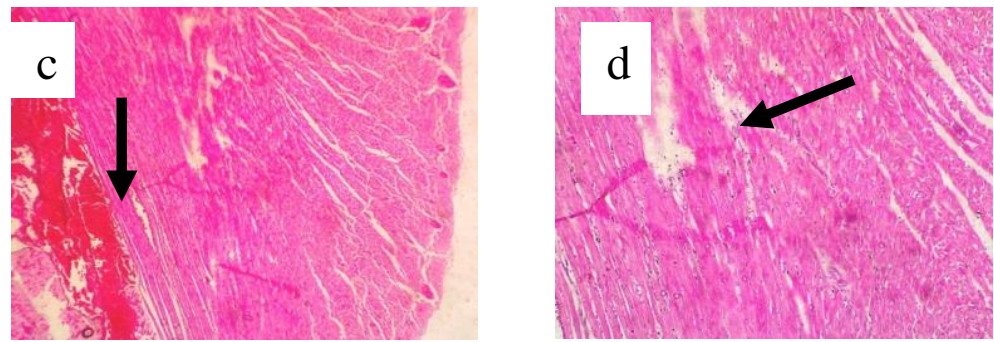

Plate 4 (c \& d): Photomicrograph of stomach (T3 \& T4) exposed to ochratoxigenic mould contaminated feed. H\&E X100: showing ulceration compared with T1 and T2.
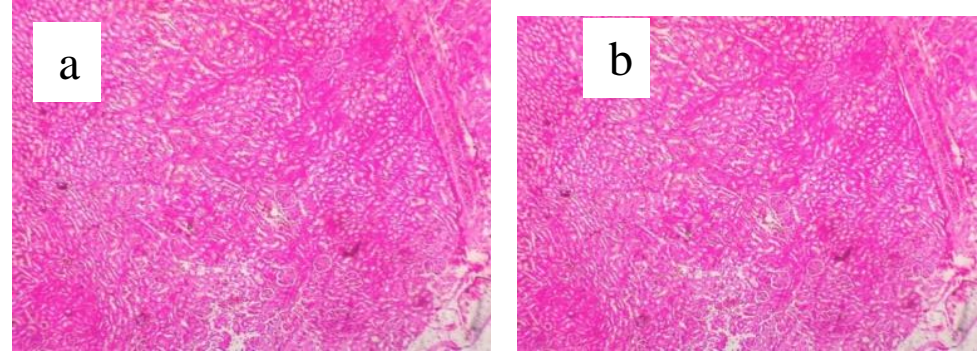

Plate 5 (a \& b): Photomicrograph of T1 and T2 small intestine, H \& E X100: showing normal architecture of the small intestine. 
Thomas at al. - Pathological scanning of ochratoxigenic moulds impaired feed in vivo ...
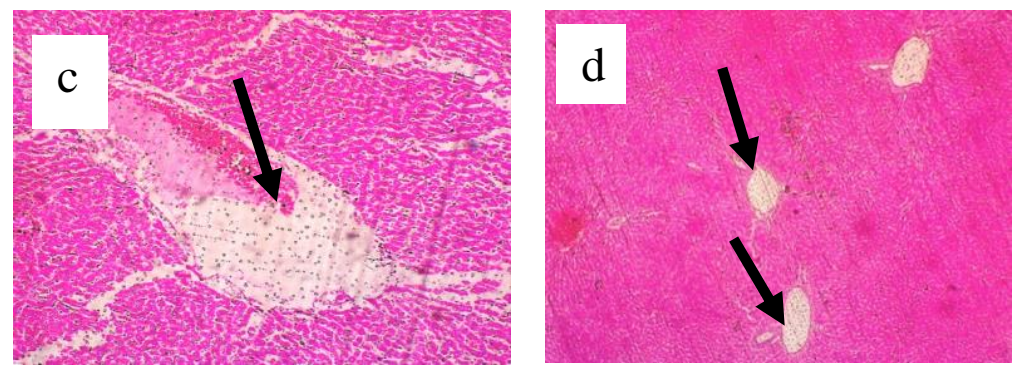

Plate 5 (c \& d): Photomicrograph of small intestine (T3 \& T4) exposed to ochratoxigenic mould contaminated feed. H \& E X100: showing alterations of mucosal linings compared with $\mathrm{T} 1$ and $\mathrm{T} 2$.
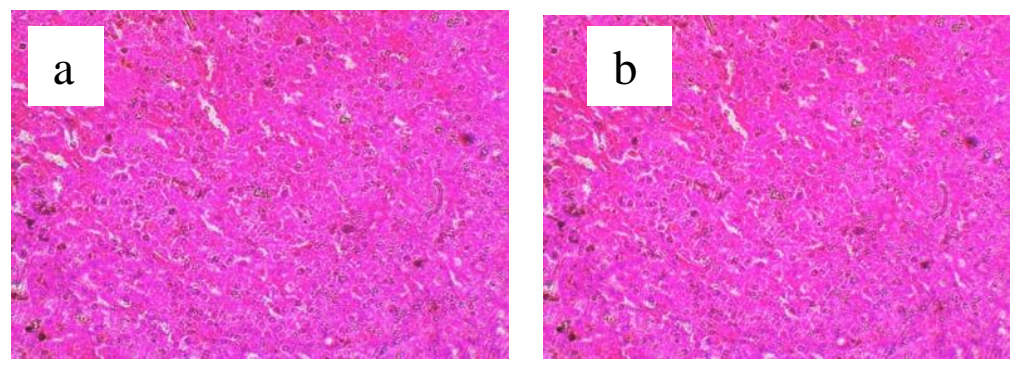

Plate 6 (a \& b): Photomicrograph of T1 and T2 lungs, H \& E X100: showing normal histoarchitecture of the lungs.
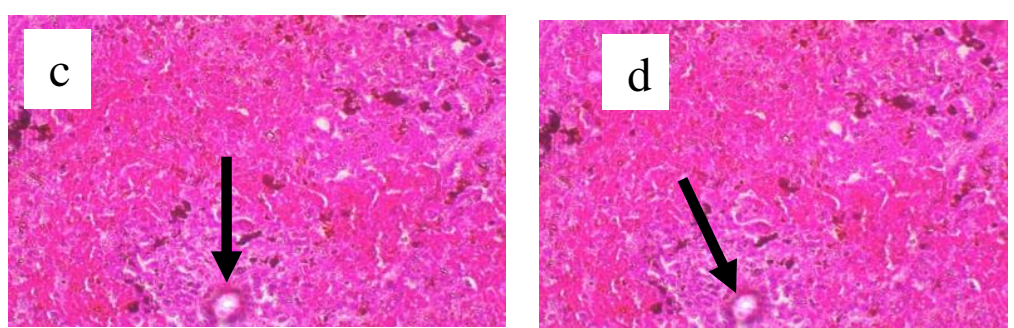

Plate 6 (c \& d): Photomicrograph of lungs (T3 \& T4) exposed to ochratoxigenic mould contaminated feed. H \& E X100: showing necrosis compared with T1 and T2.
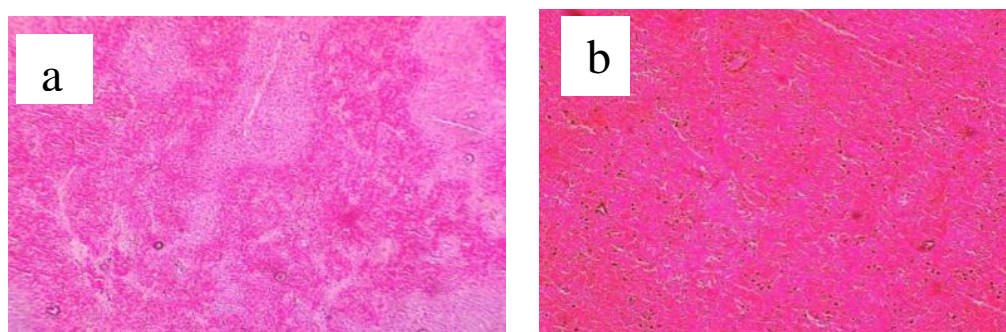

Plate 7 (a \& b): Photomicrograph of T1 and T2 brain. H \& E X100: showing normal histoarchitecture of the brain. 

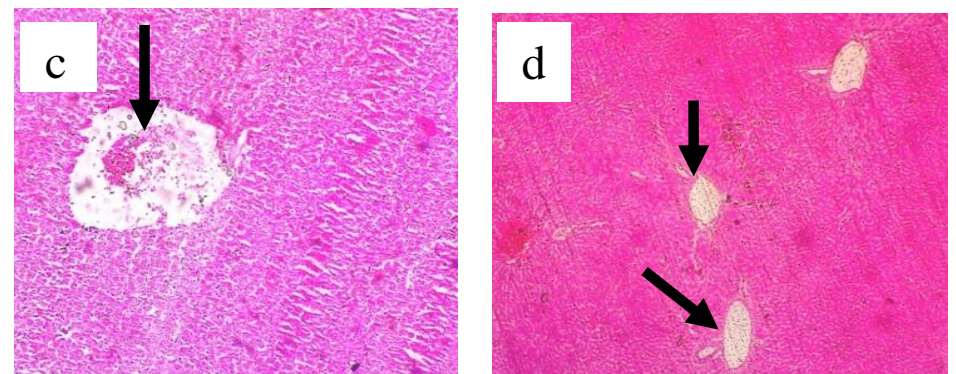

Plate 7 (c \& d): Photomicrograph of brain (T3 \& T4) exposed to ochratoxigenic mould contaminated feed. H \& E X100: showing multiple apoptotic cells at the hypocampus compared with $\mathrm{T} 1$ and $\mathrm{T} 2$.
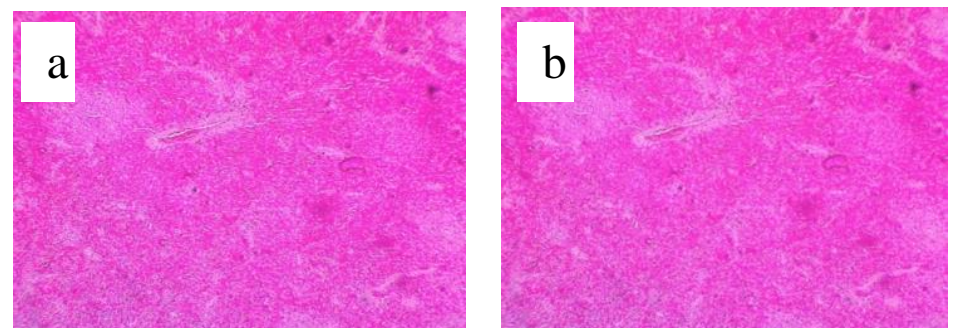

Plate $8(\mathbf{a} \& \mathbf{b})$ : Photomicrograph of $\mathrm{T} 1$ and $\mathrm{T} 2$ spleen. H \& E X100: showing normal histoarchitecture of the spleen.
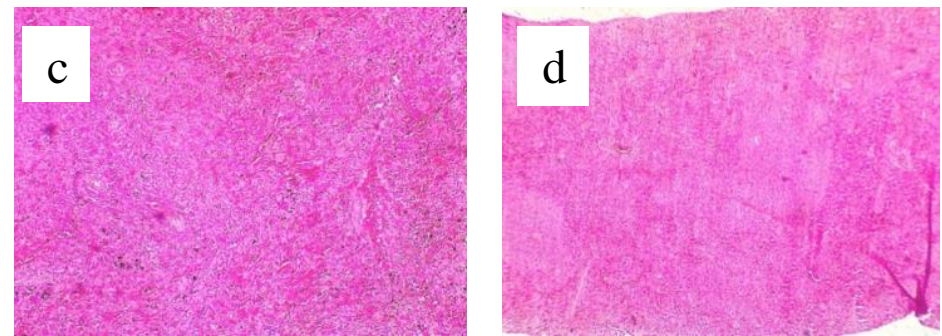

Plate 8 (c \& d): Photomicrograph of spleen (T3 \& T4) exposed to ochratoxigenic mould contaminated feed. H \& E X100: showing no damages compared with T1 and T2.

\section{Discussion}

The role of ochratoxigenic moulds in the production of secondary metabolites during their growth in tissues and their subsequent implication in the cause inflammation and/or infections has been noted (McCarthy et al. 2014) among other pathological problems (WHO 2009). The elevated rise in serum levels of total protein, albumin, AST, ALT, ACP and ALP of ochratoxigenic mould contaminated feed exposed rats observed in this study may not be unconnected to the damage caused to the hepatocytes, since it has been long asserted that increase levels of these enzymes occurs after great cellular damage (Lin et al. 2000). These cellular destructions to the liver cell as represented by the elevated levels of serum enzymes significantly connoted abnormal presence of oedema, necrosis and blood retention. In another vein, Dreisbach and Lertora (2008) also opined that the more severe the liver damage, the higher the release of the liver enzymes. These observations are not unexpected as ochratoxin-A which is the major 
Thomas at al. - Pathological scanning of ochratoxigenic moulds impaired feed in vivo ...

secondary metabolite of Aspergillus ochraceus tested in this study has been delineated as a group 2B carcinogen with hepatotoxic ability (Gayathri et al. 2015). According to Gayathri et al. (2015), this toxin exert their action on the liver by epigenetic mechanism through modification of the specialized group of cellto-cell junction (hepatocyte gap junction) apparatus and so influencing the expression of specific markers such as alpha-fetoprotein (AFP).

The fact that the biochemical parameters and histopathological examination of both male and female wistar rats tested were significantly affected may be an indication that the activities of this ochratoxin A producing Aspergillus ochraceus is not gender specific and this observation. In this research, there were significant changes in the protein levels of the treated rats as compared with the control rats to delineate significant functional changes in the normal physiology of individuals as well as blood diseases such as multiple myeloma or autoimmune diseases such as lupus, kidney disease or liver disease (Pachathundikandi and Varghese 2006). The structural integrity and architecture of the harvested organs except the spleen were impaired by the ochratoxigenic mould contaminated feeds to connote the significant negative impact of this laboratory prepared feed on the structural integrity of the organs (Iheshiulor et al. 2011). This observation corroborate the earlier observations quoted by other researchers in different literatures reporting significant consequences of such contaminated feeds on kidney (Sauvant et al. 2005), liver (Gayathri et al. 2015), brain (Monnet-Tschudi et al. 1997), small intestine (Alassane-Kpembi et al. 2019), heart (Okutan et al. 2004), stomach (Hope and Hope 2012) and lungs (Zain 2011). However, our findings were found to be paralleled to that of Xue et al. (2010) where they reported pathological disorders on the spleen of treated rats as against no pathological problem found in our own study. The histopathological changes observed in this study was further buttressed by the increased levels of AST, ALP, ACP and ALT to connote possible heart problems, pancreatitis and liver injuries among other organ injuries (University of Rochester Medical Center 2017).

\section{Conclusion}

The results obtained indicated that there were increased levels of AST, ALP, ACP and ALT to connote possible heart problems, pancreatitis and liver injuries among other organs. The results of this work however, suggest that exposures to ochratoxigenic mould contaminated feed have different reverberations on the harvested organs.

\section{References}

Akande KE, Abubakar MM, Adegbola TA and Bogoru SE 2006 Nutritional and health implications of mycotoxins in animal feeds: a review. Pak. J. Nut. 5: 398-403.

Alassane-Kpembi I, Pinton, $\mathrm{P}$ and Oswald IP 2019 Effects of mycotoxins on the intestine. Toxins 11: 1-3.

Alborch L, Bragulat MR, Castella G, Abarca ML and Cabanes FJ 2012 Mycobiota and mycotoxins contamination of maize flours and popcorn kernels for human consumption commercialized in Spain. $J$. Food Microbiol. 32: 97-103.

Amnuaykanjanasin A, Punya J, Paungmoung P, Rungrod A, Tachaleat A, Pongpattanakishote S, Cheevadhanarak S and Tanticharoen M 2005 Diversity of type I polyketide synthase genes in the wood-decay fungus Xylaria spp. BCC 1067. FEMS Microbiol. Lett. 251: 125136.

Atef HA, El-Shafei HM, Mansour MK, Al Kalamawy NM, Hassan NEHY and Lashin AI 2018 Prevalence of ochratoxigenic fungi and ochratoxin A residues in animal feeds and modulation of their toxic effects by glutathione. Int. J. Curr. Microbiol. Appl. Sci. 7(4): 2559-2582.

Dreisbach AW and Lertora J 2008 The effect of chronic renal failure on drug metabolism and transport. Expert Opin. 
Drug Metabolism Toxicol. 4(8): 10651074.

FAO 2011 Global information and early warning system on food and agriculture. FAO Food Outlook: Global Market Analysis, November.

Gayathri L, Dhivya R, Dhanasekaran D, Periasamy VS, Alshatwi AA and Akbarsha MA 2015 Hepatotoxic effect of ochratoxin $\mathrm{A}$ and citrinin, alone and in combination, and protective effect of vitamin E: In vitro study in HepG2 cell. Food Chem. Toxicol. 83: 151-163.

Hope $\mathrm{JH}$ and Hope BE 2012 A review of the diagnosis and treatment of ochratoxin-A inhalational exposure associated with human illness and kidney disease including focal segmental glomerulosclerosis. J. Environ. Public Health 2012: 1-10.

Iheshiulor OOM, Esonu BO, Chuwuka OK, Omede AA, Okoli IC and Ogbuewu IP 2011 Effects of mycotoxins in animal nutrition: a review. Asian J. Anim. Sci. 5: 19-33.

Jayeola CO and Oluwadun A 2010 Mycoflora and nutritional components of cocoa powder samples in South-West, Nigeria. Afr. J. Agric. Res. 5: 2694-2698.

Khan SH, Shamsul H, Rozina S and Muhammad AA 2011 Occurrence of aflatoxin B1 in poultry feed and feed ingredients in Pakistan. Int. J. Agro Vet. Med. Sci. 5: 30-42.

Lin SC, Chung TC, Ueng TH, Lin YH, Hsu SH, Chiang CL and Lin CC 2000 The hepatoprotective effects of Solanum alatum Moench on acetaminopheninduced hepatotoxicity in mice. Am. J. Chinese Med. 28: 105-114.

Manjula K, Hell K, Fandohan P, Abass A and Bandyopadhyay R 2009 Aflatoxin and fumonisin contamination of cassava products and maize grain from markets in Tanzania and Republic of the Congo. Toxin Reviews 28: 63-69.

McCarthy M, Rosengart A, Schuetz AN, Kontoyiannis DP and Walsh TJ 2014 Mold infections of the central nervous system. New Engl. J. Med. 371(2): 150-160.

Monnet-Tschudi F, Sorg O, Honegger P, Zurich MG, Huggett AC and Schilter B 1997 Effects of the naturally occurring food mycotoxin ochratoxin-A on brain cells in culture. Neurotoxicol. 18(3): 831839.

NRC (National Research Council of the National Academies 2011) Guide for the care and use of laboratory animals. $8^{\text {th }}$ ed. Committee for the update of the Guide for the care and use of laboratory. National Academy Press.

Okutan H, Aydin G and Ozcelik N 2004 Protective role of melatonin in ochratoxinA toxicity in rat heart and lung. J. Appl. Toxicol. 24(6): 505-512.

Pachathundikandi SK and Varghese ET 2006 Blood zinc protoporphyrin, serum total protein, and total cholesterol levels in automobile workshop workers in relation to lead toxicity: our experience. Indian J. Clin. Biochem. 21(2): 114-117.

Pozzo L Salamano G, Mellia E, Gennero MS, Doglione L, Cavallarin L, Tarantola M, Forneris G and Schiavone A 2013 Feeding a diet contaminated with ochratoxin A for chickens at the maximum level recommended by the EU for poultry feeds $(0.1 \mathrm{mg} / \mathrm{kg})$. 1. Effects on growth and slaughter performance, haematological and serum traits. J. Anim. Physiol. Anim. Nutr. 97: 13-22.

Reitman S and Frankel SA 1957 Colorometric method for the determination of serum glutamic oxaloacetic and glutamic pyruvic transainase. Am. J. Clin. Pathol. 28: 56-63.

Sauvant C, Holzinger H, Mildenberger S and Gekle M 2005 Exposure to nephrotoxic ochratoxin-A enhances collagen secretion in human renal proximal tubular cells. Mol. Nutr. Food. Res. 49(1): 31-37.

Gradwohl RBH, Sonnenwirth AC and Jarett L 1980 Gradwohl's clinical laboratory methods and diagnosis. $8^{\text {th }}$ edition, Mosby Inc., USA. 
Thomas at al. - Pathological scanning of ochratoxigenic moulds impaired feed in vivo ...

Thomas BT, Effedua H, Agu G, Musa OS, Adeyemi MT, Odunsi OD, Adesoga KO, Ogundero O and Oluwadun A 2012 Fungi associated with the deterioration of garri (a traditional fermented cassava product) in Ogun State, Nigeria. Researcher 4(2):1-5.

Thomas BT, Ogunkanmi LA and Agu GC 2014 Quelling of ochratoxin-A production by RNA interference. Glob. J. Mol. Sci. 9: 711.

Thomas BT, Ogunkanmi LA, Iwalokun BA and Agu GC 2017 Transcriptional factor influence on OTA production and the quelling attribute of siRNA on the OTA producing strains of Aspergillus section Nigri. Afr. J. Clin. Exper. Microbiol. 18(4): 210-217.

University of Rochester Medical center (Internet) 2017 Health Encyclopedia: Aspartate Transminase, cited 2017 Mar 13.
Webster D 1977 The immediate reaction between BCG and serum as a measure of albumin content. Clin. Chem. 23(4): 663665.

WHO 2009 WHO guidelines for indoor air quality: dampness and mould. WHO Regional Office for Europe scherfigsvey8 DK-2100, Copenhagen, Denmark.

Xue CY, Wang GH, Chen F, Zhang BX, Bi ZY and Cao CY 2010 Immunopathological effects of ochratoxin-A and T2 toxin combination on broilers. Poultry Science 89: 1162-1166.

Zain ME 2011 Impact of mycotoxins on humans and animals. J. Saudi Chem. Soc. 15(2): 129-144. 